\title{
Articles
}

\section{The Discourses of Mediation and the Power of Naming}

\author{
Sally Engle Merry*
}

Considerable recent scholarship in law, the social sciences, and literary theory has explored the ways law acts as an important site for the construction of meanings, for the creation of authoritative pictures of the way things are. ${ }^{1}$ The Critical Legal Studies movement has helped to push legal scholarship to examine not only the effects of law but also its constitutive role: the way it creates a social world through its categories, principles, and assumptions. Scholars in the social sciences as well as in law are increasingly interested in the power law exerts through its constitutive ca-

* This article is adapted from Getting Justice and Getting Even: Legal Consciousness Among Working-Class Americans (Univ. of Chicago Press, forthcoming 1990). The research described here was supported by a grant from the Law and Social Sciences Program of the National Science Foundation, \# SES-86-06023, and from an earlier National Sciences Foundation Grant with co-principal investigator Susan S. Silbey, \# SES-80-12034. I appreciate the contributions to this article by Susan S. Silbey in our collaborative work and by the members of the Amherst Seminar on Legal Ideology and Legal Process.

1. Much of this literature draws on interdisciplinary work in law, philosophy, anthropology, sociology, and literary studies, building generally on work by Foucault, Bourdieu, Gramsci, E.P. Thompson, Geertz, Turner, Lévi-Strauss, Derrida, Goffman, and Habermas among others. See Gusfield, Sociology and the Humanities Closing the Gap, Footnotes, Feb. 1989, at 1. 
pacity. ${ }^{2}$ Law not only constructs authoritative visions of the social world, of course, but also exerts force behind these interpretations. ${ }^{3}$

One aspect of the power of law is its ability to establish a dominant way of construing events and to silence others, thus channeling and determining the outcome of legal proceedings. Legal processes can be seen as performances in which problems are named and solutions determined. These performances include conversations in which the terms of the argument are established and penalties specified. The ability to structure this talk and to determine the relevant discourse within which an issue is framed-in other words, in which the reigning account of events is established-is an important facet of the power exercised by law. ${ }^{4}$

This article is an ethnographic study of the ways the process of naming in mediation sessions and in the lower courts exerts a form of cultural

2. See, e.g., Special Issue: Law and Ideology, 22 L. \& Soc'y Rev. 625 (1988) (edited by the Amherst Seminar). See also Brigham, Rights, Rage, Remedy: The Construction of Legal Discourse, 2 Stud. Am. Pol. Dev. 303 (1987); Harrington \& Merry, Ideological Production: The Making of Community Mediation, 22 L. \& Soc'y Rev. 709 (1988); Yngvesson, Making Law at the Doorway: The Clerk, the Court, and the Construction of Community in a New England Town, 22 L. \& Soc'y Rev. 409 (1988).

3. See Silbey \& Sarat, Critical Traditions in Law and Society Research, 21 L. \& Soc'y Rev. 165 (1987).

4. There have been several recent studies of conflict and court talk which analyze, in various ways, how this talk creates meaning. See, e.g., Mather \& Yngvesson, Language, Audience, and the Transformation of Disputes, 15 L. \& Soc'y Rev. 775 (1980-81); Arno, Structural Communication and Control Communication: An Interactionist Perspective on Legal and Customary Procedures for Conflict Management, 87 Am. Anthropologist 40 (1985); O'Barr \& Conley, Litigant Satisfaction Versus Legal Adequacy in Small Claims Court Narratives, 19 L. \& Soc'y Rev. 661 (1985); Weissbourd \& Mertz, Rule-Centrism Versus Legal Creativity: The Skewing in Legal Ideology through Language, 19 L. \& Soc'y Rev. 623 (1985); Brenneis, Straight Talk and Sweet Talk: Political Discourse in an Occasionally Egalitarian Community, in Dangerous Words: Language and Politics in the Pacific 69 (Brenneis \& Myers, ed., 1984); Sarat \& Felstiner, Law and Strategy in the Divorce Lawyer's Office, 20 L. \& Soc'y Rev. 93 (1986); Sarat \& Felstiner, Law and Social Relations: Vocabularies of Motive in Lawyer/Client Interaction, 22 L. \& Soc'y Rev. 737 (1988).

Comaroff and Roberts have developed an analytic model which helps to understand what happens in mediation sessions and court. They describe the process of constructing an interpretation in disputing situations as the development of a "paradigm of argument," which they define as, "a coherent picture of relevant events and actions in terms of one or more implicit or explicit normative referents." J. Comaroff \& S. Roberts, Rules and Processes: The Cultural Logic of Dispute in an African Context 84 (1981) (emphasis in original). A paradigm of argument is a particular construction of the situation of dispute which orders facts around normative referents. Arguments may take place within the paradigm, when normative referents remain unquestioned, or a disputant may introduce a competing paradigm based on different normative referents. In the latter case, the facts may not be contested, only their interpretations. If the case is heard by a third party, such as a chief, he or she may order a decision within the agreed paradigm, choose between rival paradigms, or impose a fresh paradigm on the dispute. Id. at 85. Analyzing disputing in terms of competing construals of events and selves within particular normative frameworks is, consequently, a useful way to examine the discursive power of law.

"Facts," of course, do not exist separate from the interpretations placed upon them. But the existence of "facts" separate from law is fundamental to the contemporary culture of Anglo-American law, although it is not a distinction shared by other legal systems. See C. Geertz, Local Knowledge: Further Essays in Interpretive Anthropology (1983). As carriers of this culture of law, American disputants tend to see mediation and the courtroom as places to argue about "facts" by presenting evidence. This is, however, their cultural construction of the scene, and, as we will see, is only one possible way of understanding the meaning of the conversations which take place about conflicts in mediation and court. 
domination over the people who bring their interpersonal problems to court. Mediation sessions, lower court magistrate's hearings, and lower court trials of family and neighborhood problems are instances of talk in which individuals present images of themselves and events in ways designed to justify and convince. The conversation is a contest over interpretations of ambiguous events. Did the children throw rocks at the neighbor's car, or were they simply playing a stone-tossing game and hit the car by accident? Did someone put a stick through the spokes of a boy's bike as he raced down a hill, or did he run into a stick, lose his balance, and fall? Were the husband's tirade against his wife's slovenly housekeeping and his angry slap instances of punishment or of spousal abuse? It is clearly difficult to determine exactly what happened in these situations and to decide what they mean. Most of the arguments in mediation sessions and lower court hearings about personal problems concern issues of meaning and interpretation, struggles to agree on what these events mean. Disputants couch their descriptions in language intended to persuade, labeling events and explaining actions in terms which they expect will be effective for both the other party and the mediator, clerk, or judge. They interpret their own actions as fair, reasonable, or virtuous and those of the other side as unfair, small-minded, and irrational. Third parties (mediators, magistrates, and, very occasionally, judges) also develop interpretations of the event and of the character of the people involved which they introduce into the discussion. Power lies in the ability to establish one or another interpretation of events and to make it stick with the rest of the group.

This article explores forms of talk deployed by people who use the lower courts and mediation programs to handle their interpersonal problems. It is drawn from four years of ethnographic research, including observations of mediation and court proceedings, interviews with parties, and participant observation in several neighborhoods. The research was carried out in two New England towns in the 1980s. The parties in these cases are primarily white, working-class, native-born Americans; it is people of this social background who tend to bring their family and neighborhood problems to the lower courts asking for help. The mediators and court officials who handle them are more middle-class: relatively more educated, affluent professionals who are also primarily white.

Based on my observations of many hours of mediation sessions and lower court proceedings, I argue that these settings include rival ways of talking about problems and events. Parties contest particular interpretations of events by arguing about which interpretive framework-which way of talking about problems and events-will define the problem. I call these distinct ways of talking and of interpreting events discourses. ${ }^{5}$ Every

5. My notion of discourse draws on Foucault. See M. Foucault, Discipline and Punish: The Birth 
discourse contains a set of categories, a vocabulary for naming events and persons, and a framework for interpreting actions and relationships. Each discourse includes an explicit repertoire of justifications and explanations for actions and an implicit, embedded theory about why people act the way they do. A discourse is usually only signalled through particular phrases or modes of explanation; it is rarely spelled out. Each is drawn from a particular normative order.

The names and interpretations I observed in the lower courts fell into three analytically distinct discourses: that of morality, of legality, and of therapy. The first is drawn from neighborhood and family life, the second from law and the legal system, and the third from the helping professions. In each case, the discourse is based on conceptions and myths of these institutions as well as on their practices. Each discourse uses particular words and phrases to evoke the authority of the institution in which it is grounded.

As they argue their cases, justify their actions, condemn those of the other side, and strive to elicit the support of the mediator or judge, parties switch discourses, testing out the effectiveness of each. Mediators, clerks, and judges also struggle to establish and maintain a particular discourse, but they, too, switch when one seems unproductive or leads to trouble. In the course of mediation sessions and court hearings, all three discourses usually appear in the discussion, raised by different parties who try them out, see if they work, gauge the response from the other participants, and shift the discussion in order to further the argument. Commonly, a person who is not succeeding in one discourse will shift to another to see if it is more effective.

The successful naming of an action or event within a particular discourse, thereby interpreting its meaning and assessing the motives behind it, is an act of power. ${ }^{6}$ The same event, person, action, and so forth, can be named and interpreted in very different ways. Each naming points to a solution. If the family problem is interpreted as caused by a mean and vengeful father, the solution is different than if it is caused by a father who, afflicted with the disease of alcoholism, becomes hostile under its influence. The ability to name and interpret is therefore a central feature

of the Prison (1977); M. Foucault, Power/Knowledge: Selected Interviews and Other Writings, 197277 (1980).

6. Weissbourd and Mertz point out that law engages in "routine creativity" when particular events are categorized as legal types, even in the most ordinary and uncontested cases, such as those I am discussing. Weissbourd \& Mertz, supra note 4, at 640. Sarat and Felstiner have explored the power inherent in attributions of motive in interactions between divorce lawyers and their clients. See Sarat \& Felstiner, supra note 4. Murray Edelman's work represents an important analysis of the political meanings of talk of all kinds, including legal talk. See M. Edelman, Political Language: Words that Succeed and Policies that Fail (1977). From a slightly different angle, Sally Humphreys points out how, from a comparative perspective, law itself constitutes a discourse. See Humphreys, Law as Discourse, 1 Hist. \& Anthropology 241 (1985). 
of the power exercised by those who handle problems. ${ }^{7}$ Disputants contest this power, however, since they also strive to establish names for the problems. Since names are part of discourses, the contest over naming is largely over which discourse will be applied to the problem at hand. Critical to the power of any participant in these disputes is his or her ability to determine the reigning discourse. ${ }^{8}$

Participants in these discussions have unequal power to establish discourses, however. Mediators and court officials wield the additional power of their institutional authority. Furthermore, they ask the questions, direct the process, and establish its procedures. They often have more expertise in some of the discourses than the parties, particularly in legal and therapeutic discourse. Thus, when they tell one of the parties that the problem he or she thought was a legal problem is really a moral one, their institutional affiliation with the court or mediation program and their training and experience give this opinion weight greater than that of the parties. The discourses themselves also seem to have unequal authority. Legal and therapeutic discourse, both professionally derived, seem to convey greater authority than does moral discourse, in which all participants share equal expertise whether or not they have professional training. Thus, as mediators and court officials pressure parties away from the more powerful discourse of law to that of morality, they disempower them by teaching them that the more powerful discourse is inappropriate for their problems.

In mediation and court discussions of personal problems, third parties typically encourage the people in conflict to engage in a reconstruction of the conversation from a struggle over "facts" and legal charges to debates over relationships, fairness, and therapeutic needs. In mediation, parties are pressed to reformulate their problems in terms of morality and help rather than in terms of legal claims, evidence, or complaints. Lower court officials also urge parties with interpersonal problems to think of their problems in moral terms rather than in terms of legal violations. Third parties raise legal discourse only to threaten serious consequences when someone refuses to settle in a moral or therapeutic vein. By reframing their problems in moral rather than legal terms, mediators and court officials encourage plaintiffs to think that their problems are not worthy of court attention. The ways in which interpersonal cases are processed diminishes the sense of legal entitlement shared by these working-class court users and discourages them from thinking of themselves as entitled to legal

7. See Mather \& Yngvesson, supra note 4; Silbey \& Merry, Interpretive Processes in Mediation and Court (1987) (paper on file with authors).

8. Mather and Yngvesson's analysis of dispute transformation identifies the role of the audience to a dispute in defining its meaning. See Mather \& Yngvesson, supra note 4. See also Santos, The Law of the Oppressed: The Construction and Reproduction of Legality in Pasargada, 12 L. \& Soc'y Rev. 5 (1977). 
help for their problems. Thus, the law denies them their sense of legal entitlement.

The following analysis describes in detail how plaintiffs' sense of legal entitlement is denied. Through the process of naming problems in moral or therapeutic discourse rather than in legal discourse, court officials tell parties that their sense of legal entitlement is wrong. This is a face of the cultural domination exercised by law. In the next section of the article, I describe each discourse. The subsequent section describes in more detail the mediation and court processes and the research study which form the basis for this article. The third section examines three cases which illustrate the interplay of these discourses. The conclusion considers the significance of the power of naming for legal processes and for the people involved in them and argues that the use of naming by legal institutions constitutes a form of cultural domination.

\section{The Discourses}

\section{Moral Discourse}

This is a discourse of relationships, of obligations between neighbors, parents and children, and brothers and sisters. Its language of responsibilities and obligations is grounded in definitions of relations between neighbors, spouses, parents and children. Interpretations are judgments of role behavior: whether neighbors should be quiet at night, whether Mary is a good mother, whether Joe should stop drinking, whether Susie "mouths off' at her parents too much. Court officials and mediators sometimes judge the behavior of the people they see and tell them that they should behave differently, stop drinking, take better care of their children, and treat each other like neighbors. Privately, mediators and court officials talk about "flakes," "crazies," "people who bring garbage cases," "a nice boy," "good-hearted," applying this discourse to the people they see. This is the talk of everyday life, a talk people share without specialized training. Solutions to problems framed in moral discourse rest on a reciprocity of fairness, reasonableness, and compromise. Agreements in this discourse detail rules of housework, of polite social interaction, of the importance of treating one another "as neighbors," "with respect," "as strangers." This discourse grows out of the normative ordering of family and neighborhood life.

\section{Legal Discourse}

This is a discourse of property, of rights, of the protection of one's self and one's goods, of entitlement, of facts and truth. Legal labels for wrongs such as "harassment," "assault," "breach of contract," "malicious damage," "trespass," constitute the core of this discourse. Reference to evidence, to the presentation of documents, written lists, pictures, and wit- 
nesses also plays a part. Some individuals invoke the "rule of law," or rights to privacy, protection, or freedom from harassment. Some demand lie detector tests. Solutions to problems depend on weighing evidence and determining the applicable rules. Disputants demand protection, insist that "something be done to stop this situation." The meanings and rights of being a homeowner, for example, are central to this discourse.

Legal discourse in these terms does not necessarily refer to particular laws or legal doctrines, but may articulate general understandings of legal relations and procedures, notions of contract, of property, and of decisionmaking based on rational discussion and the presentation of evidence in order to determine "the truth." These general legal categories are not much different from political and religious concepts of the self and its boundaries. Parties are rarely aware of particular rules or doctrines that a court might bring to bear on their cases, but instead have a general sense of fairness that derives from conceptions of property rights, contract obligations, and rights to personal security. For example, a landlord whose tenant left without the required thirty-day notice made no effort to rent his apartment for thirty days, instead taking the tenant to small claims court. He did not realize he had a legal "duty to mitigate" his loss. The small claims court judge, as a result, refused to grant the landlord the full month's rent as damages because he had failed to try to rent the apartment. Similarly, homeowners in neighborhood cases often hold notions of unlimited rights to control activities on their property. They say they are entitled to throw anyone off their property at any time. These people refer to general legal concepts, not to specific laws or court interpretations, about which they usually know little. Nor are they aware of the details of evidentiary rules, beyond the general recognition that written lists, diaries, and pictures are more persuasive than talk. ${ }^{10}$

9. Stone's distinction between essential legal relations and the particular laws derived from these relations is helpful in understanding this legal discourse. See Stone, The Place of Law in the Marxian Structure-Superstructure Archetype, 19 L. \& Soc'y Rev. 39 (1985). Working from Engels' discussion of two distinct but related concepts of legal superstructure, Stone differentiates between the legal conceptions central to the capitalist economic order, such as property, contract, and credit, and specific laws based on these essential legal relations. It is possible to have changes in specific laws along with continuity in the general concepts. "Essential legal relations" are those legal relations that mirror and define the fundamental economic relationships in a society. Id. at 50 . Particular rules are derivative subrelations. If particular rules are contradictory, the system can survive as long as these essential legal relations are not challenged. Stone suggests that capitalist societies are flexible and adaptive, surviving despite many changes in rules and many rules that conflict with the interests of capitalists, and even restrain or limit property or contract rights, because these rules do not challenge or transform the fundamental legal relations themselves: those of contract, property, and the corporation, which have remained stable over a long period of time and are now embedded in the taken-forgranted social order. Id. at 50-64. The legal discourse of working-class Americans in court provides further evidence of the extent to which these concepts are embedded in American culture.

10. Some people brought witnesses with them, even though the witness had not seen the incident, so that the witness could attest to their character and their credibility. This situation is intriguingly similar to the way witnesses are invoked by the Islamic qadi judge who, according to Rosen, relies heavily on oral testimony from morally upright individuals to assess both the meaning of the event and the character of the persons involved. See Rosen, Equity and Discretion in a Modern Islamic 


\section{Therapeutic Discourse}

This is a discourse drawn from the helping professions, one which talks of behavior as environmentally caused rather than based on individual fault. Crowding, stress, or low levels of tolerance for frustration are blamed for offensive behavior rather than inborn evil, lack of consideration, or a lack of respect. Offensive behavior is held to be socially caused, not the result of individual will, and therefore thought to require particular kinds of solutions: "He is not well. I don't want him to go to jail, I just want him to get help." The model of disease, which describes difficulties without attaching fault or blame, is the dominant explanation for behavior in this discourse. References to alcoholism, mental illness, "actingout," and emotional immaturity frequently appear. Offensive behavior is not seen to reveal innate evil but instead to manifest a need for help. Solutions depend upon "treatment" or "cure" for the person with the problem. This discourse sometimes links physical ills with emotional problems. For example, some men describe their problems with explosive violence as the result of high blood pressure, or people talk about the pressure a conflict exerts on their nerves. Some talk about their "issues," rather than their anger.

This discourse withholds judgment, but, it seems to me, by constructing an image of the person described as lacking full responsibility for himself. Although it is more compassionate, it is at the same time disempowering. The individual, "understood" within therapeutic discourse, is less than a full adult since less is expected of him or her and therefore he or she cannot be blamed. He has a disease, a problem. Thus, the control inherent in the therapeutic discourse is different from that of the legal, which refers to rights and evidence. It is, nevertheless, potent. Therapeutic discourse can also be used to label and condemn, without any concomitant theory of environmental causation and blamelessness. For example, one man asserted quickly, of the other party, "She's crazy-been in and out of the mental hospital. Don't listen to her."

The three discourses are sometimes raised explicitly in discussion, but to a large extent they are taken for granted. They serve as generative schemes through which an apparently objective social world is created." Although sometimes the product of explicit instruction, they come to seem part of the natural order of the world.

By frequency of use, the dominant discourse in both mediation and pretrial court processing is moral discourse. ${ }^{12}$ Legal discourse is pulled into

\footnotetext{
Legal System, 15 L. \& Soc'y Rev. 217 (1980).

11. See P. Bourdieu, Outline of a Theory of Practice (1977).

12. There is a fourth possible discourse, that of community and commitment, but I did not hear much of it in these mediation sessions nor in the courtrooms. It refers to obligations between individuals in terms of the responsibilities they hold to a particular community which defines expectations and determines obligations for its members. It is rarely present, although in different periods and in differ-
} 
the discussion from time to time and most participants refer to therapeutic discourse as well. Some people seem more attached to one discourse than to another. There may be some gender variation in the mobilization of discourses. In the cases I have looked at, men tend to rely more strongly on legal discourse and women on therapeutic. The following cases illustrate this gender difference. Different kinds of problems also are associated with particular discourses. Some types of problems tend to be discussed more extensively in legal discourse, such as neighborhood problems, while others dealing with marital and family issues are more likely to be phrased in terms of therapeutic discourse, probably because it is in the ordering of family relationships that the helping professions have been most heavily engaged. Moral discourse predominates in the discussion of all types of problems, although it is less pervasive in neighborhood disputes.

\section{Mediation and The Lower Courts}

Mediation programs in the United States are typically attached to courts, they take cases referred from courts, and they return cases to court if the parties fail to reach an agreement or if they fail to abide by it. ${ }^{13}$ The mediation process is generally a free-ranging discussion in a private, informal place carried out under the supervision of lay people who have had thirty to forty hours of training in mediation techniques. Mediation sessions typically last an hour or more and are concluded in a single sitting. The basic approach advocated in mediation training is developing listening skills, looking for the underlying issues, searching out points of agreement, helping the parties to see positive things about each other, and encouraging them to define an area of common ground. There is, of course, wide variation in particular mediation techniques and philosophies, but the general orientation is to provide a process which facilitates communi-

ent parts of the United States, it has been powerful. See R. Bellah, R. Madsen, W. Sullivan, A. Swidler \& S. Tipton, Habits of the Heart: Individualism and Commitment in American Life (1985). This discourse makes reference to local traditions, to "This is the way we do things here," or "This is the way it has always been done." Although communal discourses do not seem to be rooted in neighborhoods in the areas I studied, they are found in institutions such as companies, schools, the military, factories, and so forth, where they grow out of "private governments" which generate their own formalized structure of rules, procedures for decision-making, and codes of ethics. See Macaulay, Images of Law in Everyday Life: The Lessons of School, Entertainment and Spectator Sports, 21 L. \& Soc'y Rev. 185 (1987). Such social fields symbolically imitate legality but are more or less autonomous from state power. See S. Henry, Private Justice: Towards Integrated Theorising in the Sociology of Law (1983).

13. These mediation programs are part of a movement over the last two decades in the United States and in several European and Asian countries to develop informal forums for negotiating problems outside the formal judicial process. See S. Silbey \& A. Sarat, Dispute Processing in Law and Legal Scholarship: From Institutional Critique to the Reconstitution of the Juridical Subject (1988) (Disputes Processing Research Program, Working Papers Series 8, Institute for Legal Studies, University of Wisconsin at Madison); S. Merry, Getting Justice and Getting Even: Legal Consciousness Among Working-Class Americans (forthcoming 1990). 
cation and negotiation between the parties and allows them to construct their own agreement. ${ }^{14}$

\section{The Research}

I observed three mediation programs-one connected to a lower criminal court, one to a juvenile court, and one independent-in two towns in Eastern Massachusetts over a four-year period from 1980 to 1984. Some of this research was carried out in collaboration with Susan Silbey. I also did a general ethnographic study of these towns, of the neighborhoods from which plaintiffs came, and of the courts themselves. In the course of studying these three mediation programs, I observed about 75 mediation sessions and read notes from observations of about 90 others. All were brought by plaintiffs who wanted the court to help them deal with a friend, family member, neighbor, or stranger with whom they had had trouble in their daily lives. I was interested in the way mediation functioned in different kinds of American neighborhoods and the kinds of disputes citizens take to court and to mediation programs. Consequently, I interviewed the parties after their mediation sessions and studied their neighborhoods in detail. When the cases failed to settle in mediation, I observed them when they went back to court. In addition to relying on formal interviews with 124 people who went through mediation in two of the programs, I talked informally to those who came back to court.

This research suggested that plaintiffs turn to the courts as a last resort, when they are seeking justice rather than reconciliation. ${ }^{16}$ It also delineated two styles of mediation adopted by mediators in their efforts to help parties settle cases without imposing a decision. In one approach, mediators endeavored to strike a bargain by trading off interests; in the other, they pursued a more therapeutic style by searching out underlying commitments to a relationship. ${ }^{16}$ Further, this research showed that mediation and adjudication are similar processes in the ways they construct interpretations of events and in the kinds of outcomes they impose. ${ }^{17}$

In 1981-83, I supervised a second study of a juvenile mediation program. With the assistance of Ann Marie Rochleau, we observed mediation sessions for 51 young people, interviewed 128 of the participants after mediation, and observed their cases in court. $^{18} \mathrm{We}$ also interviewed mediators, staff, and court personnel about their perspectives on mediation and court. ${ }^{10}$

14. See Silbey \& Merry, Mediator Settlement Strategies, 8 L. \& Pol'y 7 (1986).

15. See Merry \& Silbey, What Do Plaintiffs Want? Reexamining the Concept of Dispute, 9 Just. Sys. J. 151 (1984)

16. See Silbey \& Merry, supra note 14.

17. See Silbey \& Merry, supra note 7.

18. See S. E. Merry \& A. M. Rochleau, Mediation in Families: A Study of the Children's Hearings Project (1985).

19. This article is based on five kinds of ethnographic observation. First, Susan Silbey and I sat in 


\section{Problems Brought to Mediation}

Most of the problems handled in these three mediation programs concerned proper conduct and social relationships, although property issues frequently became entangled as well. These disputes fell into four main types depending on the relationship between the parties: neighbor, marital, boyfriend/girlfriend, and parent/child. Neighborhood and marital problems were most common in the caseload of programs attached to the lower criminal courts. Neighbor problems frequently involved proximity issues such as noise, dogs, trash, and children's play. Marital problems often involved incidents of drinking and violence, exacerbated by shortages of money and by different ideas of disciplining children. Boyfriend/girlfriend problems frequently involved jealousy and rivalry between young people or the efforts of parents to keep particular young men away from their daughters. Parent/child problems concerned parents' efforts to induce their teenaged children to attend school, change their friends, treat them with respect, or contribute more to the functioning of the household.

In the New England towns where I did this research, the people who brought such problems to court were largely white working-class people, native-born, in their thirties to fifties, and disproportionately female. Different types of problems were brought by different kinds of people, however. Neighborhood problems were typically initiated by older homeowners in blue collar neighborhoods, often against newcomers, sometimes in an effort to gain control of a neighborhood in which they had become a minority. Both men and women initiated these cases. Marital problems were brought almost entirely by women against men in an effort to pre-

on 118 mediation sessions and took detailed notes on each during the one to four hours it usually lasted. All of the cases described in this article are based on my own observations and interviews. Second, when cases failed to settle or the problem flared up again and came back to court, we observed them in court. I observed approximately 30 in court either before or after mediation. Third, we did a quantitative analysis of the caseloads of the two programs derived from their records, examining a total of 868 cases. Fourth, we interviewed 124 people who had been through mediation, many of whom had come to court in the first place and had had some experiences in court. We talked to them in person for an hour or more, usually in their homes. Both plaintiffs and defendants were interviewed. I conducted about 50 interviews and several research assistants did the rest. In addition, I spent hundreds of hours observing court proceedings including hearings in front of clerk-magistrates, talking informally to court personnel, mediators, and mediation program staff, and doing general historical and ethnographic work on the towns. Susan Silbey also did extensive ethnographic work in observing court proceedings and interviewing court personnel. Fifth, we did an ethnographic study of three small neighborhoods where interpersonal conflicts occurred fairly often. This included a survey of 93 residents of these neighborhoods about how often they had the kinds of problems we saw in mediation and what they did about them. The survey was part of a more intensive ethnographic study which included long conversations with several of the residents of these neighborhoods. I did the general ethnographic interviewing and background work in these neighborhoods and several neighborhood residents and students did the survey interviewing. In order to compare these working-class and lower-middle-class neighborhoods with an upper-middle-class neighborhood, in the summer of 1985 I did a similar survey and ethnographic study of an affluent suburban neighborhood. A student did the survey, while I again did more general ethnographic work on the neighborhood. See Merry, Crowding, Conflict, and Neighborhood Regulation, in Neighborhood and Community Environments 35 (I. Altman \& A. Wandersman ed. 1987). 
vent violence or to deal with shortages of money. Boyfriend/girlfriend cases were either initiated by parents trying to keep an undesirable young man away from their daughters or by young people in their teens and twenties sorting out jealousy and fights among themselves. Parent/child problems were most often brought by single mothers who were attempting to establish greater control over their children and get them to treat them with respect, to keep them from running with a "bad" group of friends, or to get them to go to school.

In the terms developed by others who have studied the American working class, the people involved in neighborhood and parent/child cases tend to belong to the more "settled-living" parts of the working class, while people involved in marital and boyfriend/girlfriend cases are more "hardliving," with less stable jobs, family lives, and financial situations. ${ }^{20}$ In general, the people who come to court are from those groups that have been displaced by the economic transformation of New England and its loss of blue-collar jobs, and by the revitalization of cities and the gentrification of working-class and poor urban neighborhoods. ${ }^{21}$ The blue-collar jobs have been replaced by highly skilled technical jobs and low-paying service jobs.

Overall, plaintiffs are neither educated professionals nor the welfare poor, but rather people with a high school education or a few years of college who have low-paying technical, service, or blue-collar jobs. A substantial minority are people who are retired, unemployed, or at home. Their incomes are usually below the average for the town they live in. Yet they are people who feel entitled to the help of the courts when they face intransigent problems and difficult, uncooperative adversaries. They go to court reluctantly and as a last resort, seeking to assert rights to protection from violence, from abuse, and from violation of their property. They understand these rights not as they are defined in the law, however, but as an aspect of their general political consciousness.

Mediators are volunteers who come from the same towns as the parties. However, they are generally of a higher social status: most have college educations and many have advanced degrees, particularly in law and social work. They have higher incomes and more stable family lives, and live in more affluent parts of town. In the mediation programs I studied, they were disproportionately women. All three mediation programs made a serious effort to balance their mediator pool in terms of gender, race, and age, but because of the social composition of the towns, the time demands of the work, and the disproportionate appeal to women, those available to mediate tended to be older, white, relatively more educated,

20. See J. Howell, Hard Living on Clay Street (1973); L. Rubin, Worlds of Pain: Life in the Working Class Family (1976).

21. See B. Bluestone \& B. Harrison, The Deindustrialization of America: Plant Closings, Community Abandonment, and the Dismantling of Basic Industry (1982). 
and female. Moreover, because in all the programs, the more professional mediators were seen to be more skilled and consequently were invited to mediate more often, most of the cases were handled by white, middle-aged women who had some professional experience, often in the helping professions.

The class and educational background of court officials is similar. In court, these problems are typically handled only by clerk-magistrates. Most but not all clerk-magistrates have law degrees. They are political appointees and are usually well connected with the political system of the town. On rare occasions, these cases are handled by prosecutors and very rarely, by a judge. In the juvenile court, parent/child problems are handled by probation officers as well as judges. The backgrounds and training of prosecutors, probation officers, and even judges are similar to those of the volunteer mediators: they are locally oriented people with a college education, usually with advanced training in law or the human services.

As a result of the ways mediators are selected and trained, they tend to be more educated and of a higher social class than the parties. ${ }^{22}$ Thus, they, as well as the court officials, speak in a manner that conveys to the parties greater education and greater professional expertise than the parties have. For working-class Americans, this form of speech implies knowledge and education. Working-class Americans typically endow such people with authority at the same time as they resent that authority. As a middle-aged white woman who had taken her husband to court for beating her put it, "For professional people, butter melts in their mouths. They are treated a lot better."

This study examines the way working-class plaintiffs interact with the legal system as they bring their family and neighborhood problems to court for help. Here they encounter people who are more educated and have a higher social class background. These people-mediators and court officials-speak with the authority of a greater mastery of the discourses one learns in school, particularly those of the law and the helping professions. As they seek to persuade the plaintiffs that their problems are not really legal problems but just matters of how neighbors and family members should treat one another, their education and their mastery of the more arcane discourses of legality and therapy buttress their authority. Because they are more able to speak, they silence the claims of the parties by disrupting the efforts of the working-class plaintiffs to deploy the more powerful discourse of the law and channeling these efforts into the discourse of morality. 


\section{Three Cases in Mediation and Court}

The following three cases, two neighborhood disputes and a boyfriend/ girlfriend problem, illustrate the discourses and their interplay as a problem moves through mediation and court. In each case, the mediator or court official eventually succeeds in establishing the reigning discourse. In doing so, he or she converts a problem which the plaintiff has framed as legal into a moral or therapeutic one. The plaintiff is shown that the problem that brought him or her to court is not really a legal case and does not really involve rights and evidence, but instead is a matter of how people relate to each other. Consequently, he or she is urged to see that legal remedies are not necessary. Thus, the practice of shifting discourses provides a way to discourage plaintiffs from using courts for their interpersonal problems and a means of persuading them that the courts are not the right place for these problems. Reframing is one way plaintiffs are "educated" not to use the courts and are helped out the door.

Reframing is an aspect of the power of naming, the power to assert what a problem is and what should be done about it. In these settings, naming is done by people who are perceived to hold particular authority by virtue of their institutional location and their professional expertise, an authority often revealed in their language. Consequently, plaintiffs are persuaded to acquiesce to these names, to abandon their efforts to get help from the court for problems defined in legal terms, and to accept the court's redefinition of the problem as a social one deserving ongoing supervision of their social relationships. The power of naming thus represents another facet of the power of the law, a power that stretches beyond its directly coercive capacities.

\section{Neighbors}

This problem takes place in a densely populated working-class neighborhood. It grows out of subtle differences in social class: a newcomer plaintiff who feels slightly above his neighbors and an old-timer female defendant who has a more hard-living life style. There is a boy at the center, the defendant's son, whom everyone agrees is aggressive. The plaintiff himself is a man who by his own account as well as that of others is an angry person. The description of the situation comes from interviews with both parties, a visit to the neighborhood, and my observation of the mediation session.

The plaintiff in this situation comes to court with his complaint framed in legal discourse: rights to privacy, to property, to being left alone. He accuses the neighbor's teenage son of harassing and bothering his son and his family. It is a case of a man enraged by neighborhood children. The two boys have been fighting with each other, throwing rocks, and calling names. The plaintiff buttresses his claim with "official evidence." The 
mediators persuade him to reframe it in moral discourse. They ask about the relationship between the boys, whether they were friends in the past, whether they ever got along, and why the friendship disintegrated. They persuade the defendant to define the problem in moral discourse as well, although her initial position was already framed in moral discourse. From time to time, she refers to legal discourse by bringing up property rights and to therapeutic discourse by talking about the psychological problems of one of her children and of the plaintiff.

Bobby, the aggressive fourteen year old, repeatedly fought with his neighbor, George, a man in his thirties. ${ }^{23}$ George and his wife Betty both work, he as a salesman and she as a secretary. Betty has some college education but not a college degree. Together, they earn between $\$ 25,000$ and $\$ 35,000$ a year and own their own house. They moved into the neighborhood three years ago. He had been in the military for several years, traveling all over the world, and served in Vietnam. Their only child, a ten-year-old boy, spends the afternoons at home alone. Across the narrow street in a neighborhood of small single-family and duplex houses lives Bobby's family. His mother, Jane, a divorced woman with five children ranging in age from 2 to 15 years, struggles to survive on less than $\$ 12,000$ a year. She has a high school diploma. Her ex-husband is a police officer in town. Her oldest son (not Bobby) has emotional problems. She has lived in town for 16 years and in her present house for seven. She owns the house. Jane is an attractive, vivacious woman in her thirties; George is an intense man, Betty more gentle and quiet. Jane and Betty grew up together in a nearby neighborhood, but were not close friends.

A series of incidents occurred between the two families, primarily involving confrontations between Bobby and George: Bobby threw eggs at George's car, George overturned a picnic table in Jane's yard, and both made obscene phone calls to each other. George then went to court and filed a complaint against Bobby charging him with annoying telephone calls and harassment. The description on the complaint form reads as follows: ${ }^{24}$

Repeated obscene telephone calls, damaging personal property, constant harassment from said family. Death threats to my 10 -year-old son and flashing knives. Constantly threatening my son on the way to and from school and while playing on and around our own property. Has thrown eggs at my property on numerous occasions.

At the clerk's hearing, which I did not attend, the clerk refused to issue

23. Here, as in all the other cases, I have changed names and some personal details in order to conceal the identities of the individuals involved. Since I was not allowed to tape-record mediation sessions or court hearings, talk is based on my detailed notes taken at the time. Unless otherwise noted, the text of the sessions is not direct speech but my best efforts to reconstruct what people said.

24. I am indebted to Barbara Yngvesson for the information on the complaint application form. 
the complaint and referred the case to mediation, over George's intense and angry objections. Jane was willing to try mediation.

At the mediation session three weeks later, which I did attend, the two mediators introduced themselves, described the procedure of public and private sessions, emphasized the confidentiality of the private sessions, and noted that they hoped the parties would reach an agreement, which would be put in writing. If they did reach an agreement, one copy of the signed document would be left with the mediation program. The mediators emphasized that they had taken an oath of confidentiality from the court and that the only written record of the session would be the agreement. Thus, they defined the event as private, connected to the legal system, and governed by explicit rules of procedure. Only George, Betty, and Jane were present for this session; the children did not come.

George, as complainant, was invited to begin. He began to describe the situation in everyday terms.

This has been going on for two and a half years. No one is totally innocent in the situation. I've ignored things and so have they, but things are now getting out of hand. They are quieter, then things start up again. Now there is catcalling, abusing people, abusing property.

The mediators press him to be more specific about the nature of his complaint about Bobby, in particular. He replies that there was a phone call in which the boy said obscene things, and that last spring, he got a call from his son in the afternoon that Bobby was chasing him home from school with a knife.

Jane describes the situation in her initial statement, shifting between addressing the mediators and addressing George, as follows:

The complaint was harassing phone calls, but it is much, much more. George's family moved in two years ago. They have a little boy and my son was friendly with him. The problem was their son's inability to communicate with his peers. They all picked on him and the kids started to fight, especially Bobby and their son. George would intervene and start to fight with my children. This is the problem. There have been eggs thrown at both houses and we have tried to get at a resolution for the bickering. My biggest complaint is that whatever my children did to his house, George did to mine, then he boyishly admits it. He has a low frustration tolerance and quite a temper. He is childish. He has knocked over a picnic table, hit Bobby with a baseball, and I had to call the police. I am at home all the time and I see this. My son has been disrespectful to George, but he is disrespectful back. I intervene to protect their son sometimes. George once kicked in my door and my kids were afraid. George also called my son, and I wrote down what he said. I told him, when my children do wrong to you, I knock on the door and tell you, tell them 
to take the eggs off. I don't think you would do the same for me. I feel intimidated. I am recently divorced and I don't need this aggravation. And the problem is not the wife or son, it is George. I am not the type of person to call all the time and say what your son does, but it is George who has chased us and hit us. He always blames us for things we do and don't do. The day that the children were playing with wood in our back yard I was nice about it. I had an idea that other things bothered you, but you had a camera and were taking pictures. I said in court what was happening last summer, but he denied it, he was full of lies. I never damaged your property.

Both of these statements plunge the listener into the middle of the situation without providing the contextual background and history with which to situate the stories. The discourse of both is primarily moral, including assertions of one's own virtue and attacks on the moral character of the other side. Nevertheless, legal discourse is also present, particularly in George's statement about abuses of property and in his complaint application form which mentions harassment and threats of violence. George's use of legal discourse is not surprising considering that he went first to court and was persuaded by the clerk to try mediation only with great difficulty. Moreover, in their introduction, the mediators emphasized the connection between this process and the court rather than its difference.

Jane frames the problem in a more therapeutic way, blending assessments of George's character as "childish" with psychological terms such as "low frustration tolerance" and his son's "inability to communicate with his peers." But she relies primarily on moral discourse, blaming George for not talking to her directly and retaliating against a child, behavior not suited to an adult. There is subtle criticism of working parents in her statement that she is home, that she sees things. Jane refers to evidence and to legal claims as well, although largely in response to George. She has written down the text of the offensive phone call, she observed him taking pictures, presumably for evidence against her, and denies that she damaged his property. Jane's concern about George's alleged lies reveals her construction of the event as one in which truth will be uncovered and a decision made. Yet, as the following discussion indicates, assessing the "truth" of the myriad incidents in the fight is not possible; each person has their own interpretation of what went on. Yet both are concerned about lies. George responds to Jane's statement as follows:

You said in the courtroom that I threatened you, and that is a lie. You say I hit your children. I never hit your child, and the baseball was a soft ball, not a hard ball. I have never laid a hand on your child. I have never thrown an egg. I am not saying my son didn't. For the last $2 \frac{1}{2}$ years, your defense has always been that my son flipped you the finger and said "fuck you." He may have, but we have not raised our child to act that way and no one else has com- 
plained. And you always say that at every incident. He was only seven and it is not normal for a boy that age. Maybe he thought he could because your children are 10 and 12 and he sees them doing that and saying things like that to you. And he doesn't say it to us, he never talks like that to me. I know he uses discretion. He doesn't use the kind of language in our house that I hear coming from your house.

Here the conversation shifts to respectability, drawing on norms encoded in language use. This is an argument about reputation and about the obligations to treat adults with respect. George continues to list his grievances, reading from a long list written on several sheets of lined yellow paper, detailing a series of interactions with the other family. Jane replies:

This was malicious damage of people. Normal people don't do that.

Kids can get together or fight, parents shouldn't fight.

Here she deftly combines legal and moral discourse, referring to the legal charge and then asserting a general moral principle about the way adults should deal with children's conflicts. George seeks again to defend his reputation:

We have lived all over the world. My son has problems, but I have gotten along with people, worked with those I don't like, all over. We both work. You keep saying that we both work for lust of money, but we can't afford not to. We need to buy our house, which we just bought when the rates were high, not a long time ago like you did.

The argument continues over who did what to whom, intermingled with challenges to one another's reputations. Betty asks Jane if she is on welfare, and Jane says no, that she is hurt by the question. Betty says her son has no friends because Jane's sons chase them all away.

Jane admits that her kids use profanity, but does not think that excuses a grown man from becoming so involved with their fights. The complaint in court was annoying phone calls, but George called Bobby and said (she reads):

You fucking asshole, I will break your neck.

George denies the first part of the sentence but acknowledges the threat to break Bobby's neck. His wife adds that they received fifteen phone calls from Bobby that day including death threats and the threat that he had a knife. Jane retorts that her children do not have knives, and that George can get a search warrant and see. After both sides insist that they only want peace, they discuss the fact that both call the police all the time, and 
that it was the police who told George to go to court. When the mediators ask George what he really wants, he replies:

I don't want to put anyone in reform school, I just want peace, to be left alone.

The mediators encourage the parties to think about resolving the problem themselves, pointing out that the alternative is calling the police.

Do you want the police to resolve this? What do you really want?

They conclude the discussion between the parties by observing:

This is up to you to resolve. No one else will.

Thus, the mediators subtly try to persuade the parties to resolve the problem themselves instead of turning it over to the police. They ask questions about the relationship between the two families and explore whether relations were peaceful in the past or if the boys had at any time been friends. As they do so, they are searching for some basis for agreement in shared feelings or in an interest in preserving the relationship.

In her private session with the mediators, Jane says that the problem is George's character:

$\mathrm{He}$ is a very violent, dangerous man who the least little thing ticks off. And my son Bobby is not an angel. He likes to see this going on and on, and he hates George's family.

The mediators return to the strategy of painting grim pictures of the alternative to settlement:

Short of one party moving or going to counseling, there is a need to resolve this problem. As the kids get older, it may get worse, and it could get violent. Can you get Bobby to go along with the agreement?

In his private session with the mediators, George also denigrates the character of the other side. He says that he thinks Bobby is disturbed because he doesn't have a father. He admits chasing Bobby down the street but says he did not catch him. But he thinks Bobby wants to pursue the conflict. He says that Bobby says that he wants George to hit him so that he can sue him.

Throughout the mediation session, the mediators urge the parties to return next week with their children and, at the end of the two-hour discussion, they agree.

Despite the predominance of moral discourse in this discussion, legal 
discourse is not far away. Both sides sometimes raise a legal defense or present more formal kinds of evidence when it appears advantageous to them. Jane offers to have a legal search of her house for knives; Bobby threatens to sue George. George has obviously been thinking of reform school for Bobby. The discussion of lies suggests that they interpret this forum as one dedicated to uncovering "truth." There is also some therapeutic talk: George sees the possibility that Bobby is disturbed by the divorce.

The discussion is a contest over the meaning of events and over the character of the participants. These are in fact the same debate, since actions are evaluated in the light of the persons who did them. For example, Jane claims that George's retaliation against Bobby is inappropriate for an adult and she labels him a child, defining him in moral discourse. In her attempt to make sense of George's actions, she also labels him a psychologically disabled person ("low frustration tolerance"), employing a diminishing label from therapeutic discourse. Both sides in this conflict are willing to accept some responsibility for the problems; what appears to be at stake for both is retaining a positive image of themselves in their interpretation of the conflict. Legal discourse and therapeutic discourse are employed as subsidiary tools to support the image of the self created within the moral discourse.

At the second mediation session, the mediators have a long discussion with the boys alone, without parents, as well as with the parents. This discussion is couched almost entirely in moral discourse. The mediators urge the boys to think about their past friendly relationships and to stop fighting, for the sake of their families and themselves. One mediator told the boys:

You understand that these problems have gotten your parents involved and have even ended up in court. You are all saying the same things. There are a lot of childish actions involved here. We would like you to discuss the problems. You have both said you would like to be friendly, if not friends with each other, and that you are both part wrong and part right, that you both instigate things. Some of you want to live peacefully, but some of you do things to aggravate each other. We want you to talk to each other.

The mediator then urges the boys to talk directly to each other instead of getting George involved in the fights. When the mediators bring George and Betty in for a private discussion, however, George complains that he cannot accept the children's agreement to talk to each other and Jane's proposal that she will talk only to Betty and not to him, an arrangement which excludes him from communicating with the other family. 
I couldn't go along with that. It concerns our property, and damage to it.

The mediators counter that the boys have made this agreement themselves and emphasize that the boys want to be friends. The end of the discussion concerns how parents should act, what they should do if their children have conflicts, and so forth. The final agreement reads:

1. The parents, expressing full confidence in the ability of their sons to solve their own problems, agree to allow them to resolve their differences.

2. The three boys will feel free to talk with one another over any problem that may arise.

3. All agree that there will be no further harassment.

4. Jane and Betty will feel free to discuss any future problems on a one-to-one basis should the need arise. All three parents will encourage friendly terms.

The mediators call all the parties back into the room and each signs the document, with the mediators signing as witnesses. The mediators tell the parties that the mediation office will monitor the agreement, calling each person at intervals of two weeks, two months, and three months. At the beginning of the session, one of the mediators had described the agreement as an "official document." Now she reminds them,

Boys, remember, responsibility lies on your shoulders. It is now up to you to show your parents you stick by your word.

This session lasted three hours. The one the week before lasted two hours.

A comparison of the initial complaint application and the final agreement reveals a shift in the discourse from the legal to the moral. The mediators favor moral discourse and discourage legal discourse. Despite their initial framing of the mediation session as a legal setting by references to the "oath of confidentiality" from the court and the support of the court, the mediators endeavor to stick to a moral discourse, resisting both the legalistic arguments and the psychological characterizations of the parties. Several times George, in particular, shifted to a legal discourse and presented "legal" evidence. Each time, he was encouraged to think in terms of friendship, neighborly obligation, and the responsibilities of parents; his documents and pictures were ignored. He appeared to prefer a legal discourse for this problem, while the mediators preferred a moral one; Jane and Betty seemed willing to shift to a moral discourse, although they used legal discourse from time to time. The agreement itself is couched in moral discourse, indicating that by the end, this discourse dominated the framing of the problem.

All three discourses exist in the repertoires of these people, and they 
shift rather easily from one to the other. There are some individual differences, however. George is quicker to turn to legal discourse, Jane to therapeutic. George thinks in terms of a fundamental right to the protection of his property, while Jane is more inclined to use psychological labels. It seems likely that in the course of dealing with her older son's emotional problems, Jane has encountered counselors who have taught her how to use and frame issues in therapeutic discourse. In general, men were particularly likely to use legal discourse and women to draw on therapeutic discourse. Both men and women use moral discourse, however, the discourse which is least powerful in the legal context.

\section{A Boyfriend and Girlfriend}

This situation took place in a poorer neighborhood than the last. It concerned a young woman who went to court for protection against a young man who lived next door and had fallen in love with her. After she told him that she was no longer interested in him, he continued to call her, harass her, and attempt to keep her from going out on dates. She went to court to get him to leave her alone. The plaintiff had considerable experience in court and the defendant was also well known to court officials. Again, there appears to be a subtle class difference between them, with the boy of slightly lower social class. Yet both these people fall into the category of hard-living people. Neither owns his or her own home. They are more concerned about violence than respectability. I interviewed the plaintiff in her home and observed the mediation session and clerk's hearing, as well as talking with the plaintiff informally at some length. The defendant was very quiet and reserved in the mediation session. The processing of this problem in court shows that court officials, as well as mediators, reframe personal problems in moral discourse and seek to extinguish legal discourse.

As is characteristic with marital and boyfriend/girlfriend problems, the discussion takes place largely in moral discourse, sometimes moving into therapeutic talk. However, the plaintiff's initial request for help was framed in legal discourse: a request for protection from an angry man. She allows the mediators to shift the discussion to moral discourse, but when the mediation agreement fails to provide her the protection she seeks, she returns to court more assertively demanding protection. In her second experience in court, a hearing before the clerk, she is more insistent about maintaining legal discourse, detailing the incidents of violence she has suffered. The clerk persists in framing the problem in moral discourse, however, concluding with a lecture on how she should behave.

Mediators and clerks generally attempt to delegalize the discourse of people who are trying to invoke the power of the court to protect themselves and their property. As they derail legal discourse and reject cases, 
clerks and prosecutors sometimes offer advice about how the case could have been framed to generate legal action, as they do here. Thus, in justifying inaction, clerks and prosecutors provide the tools for future legal action. The court officials teach plaintiffs legal discourse. In this case, the clerk provides fairly explicit instructions to the plaintiff about how to present her problem legally: she needs to provide specifics of date, time, and place, file soon after a specific incident, and focus only on a particular event rather than a general pattern. Thus, paradoxically, at the same time that these forums derail legal discourse, they offer instructions in how to build a more persuasive legal case. Court officials inadvertently teach parties how to use legal discourse at the same time as they persuade the parties that their problems are not "real legal cases."

Bridget Jones lived on Green Street, the worst street in town, a dismal row of four-story brick tenements built in the nineteenth century by mill owners to house their recently immigrated mill workers. At 28 , she was a heavy woman with curly brown hair who looked older than her age. My impression was of a strong woman with warmth, vivacity, and caring. Bridget came to the court about a problem with a young man, Billy, who was in love with her and called her and harassed her all the time. Billy was 17 , a slight, short boy with a meek expression who sat through the mediation session slumped over and silent. He seemed very sad. He refused to be interviewed afterwards, but I talked to Bridget for about two hours in her apartment and again when her case returned to court. She seemed very self-confident, he apologetic but angry.

Bridget and Billy lived next door on Green Street for about two years. A short time before the case came to court, Bridget moved away from Green Street to the next town. A few months later she moved back to Green Street. During the two years they lived next door to each other, Billy began to babysit for Bridget's three children, aged 5, 7, and 10, and to spend a considerable amount of time at her house, talking to her and playing with her as well as with the children. She was separated from her husband at the time and confided her problems to Billy. But when Billy wrote her a love note, she told him that the relationship was off. He began to harass her, attack her and pull her hair, lie in front of her car to prevent her driving away, and call her at work all the time. He threatened to kill himself by jumping off the roof if she did not change her mind. He sometimes sat in her car and waited for her, and once she had to call the police to get him out of her car. This situation continued for about a year. Bridget said that she had threatened many times to go to court if he did not stop harassing her and had finally filed a complaint with the clerk charging him with harassment. Billy was very surprised and hurt that she had.

Billy lived with six or seven brothers and sisters and a mother who was often absent for weeks at a time. When I talked to her at her house, 
Bridget told me that Billy was often left to take care of the younger children. She said,

It was really kind of sad. He would spend all day cleaning up the apartment when his mother was coming home, and she would just come in and not notice it at all or say anything. He would do the same thing for me, clean my apartment from top to bottom. Once the little boy, the 7-year-old, and another boy, set a mattress on fire and fortunately Billy came home in time to call the fire department. But they are too young to be left alone without any one to watch them. I guess that Billy or his older brother provides food for them.

When she kept calling the police about her troubles with Billy, the police urged her to take out a restraining order against him. But according to the court, she was not eligible, since they did not live in the same apartment. She thought that the police were eager for her to take Billy to court since they thought he was a troublemaker. Based on my observations of similar cases, I suspect that the police also grew tired of coming.

At the time of this mediation session, Bridget was working as kitchen help in a local school and Billy was working in a temporary job in the post office. He had dropped out of high school. Bridget also worked off and on in a local bar.

The mediation session lasted seventy minutes. The mediation staff member who did the initial processing told the two mediators that this was a problem of a young boy with an attachment to a married woman, and that their role was to tell the boy that he had to end the relationship and stop harassing her. Thus, the problem was initially framed in moral discourse by the mediation program staff. Bridget's initial statement also presented the problem in moral discourse, adding a reference to Billy's need for help:

The problem is that he won't leave me alone. He is calling at work, bothering me all the time. This is really aggravating me and it has just got to stop. He calls me out of work down the hall to the phone several times a day. It is making me sick and getting me so aggravated. It has been going on for two years now. And furthermore, I was at a friend's house cooking dinner one day and he sent me a letter saying that he would kill himself if I didn't leave the house. It was a male friend. He is very jealous of my male friends and gets very upset if I ever talk to them. I live in the next town now, but when my husband and I were separated, I lived near Billy. He would bother me then. His sister used to babysit for my children, and I got to know him then. He would come over and play with my children. He needs someone to care about him and listen to him, and I always did that, I was always there for him. I helped him in his relationship with his girlfriend. I did this when I lived near him, but now I have moved to the next town, and this continues. He calls me 
when I am at the club [a local bar], he calls my male friends there, and he called one a black bastard. He gets very upset about all my male friends.

When the mediators asked Billy for his side, he responded only, "I have nothing to say." In the private discussion with the mediators, Billy said only that he had his reasons for harassing her, that she hurt him very much, but that he would not talk about it. When they asked Billy if he knew why she did not want to see him any more, he replied:

I don't know. I guess I am harassing her. She says so, so it must be true. And besides, she took me to court, didn't she?

He seemed here and later very angry that she had taken him to court. $\mathrm{He}$ called her several times at work the morning of the mediation session to complain to her about it. Invoking the court seemed a drastic step to him. When the mediators asked him if he could treat her like a total stranger, he replied:

It would be hard, but I could do it. And I have to, because if I don't, she will take me to court. But I could take her to court too. I could charge her with statutory rape.

With this comment, Billy shifts from moral to legal discourse, indicating that he has some power within this discourse, although it seems that he does not want to use it. The mediators do not pursue this possibility.

When the mediators ask Billy what he would like to see in the agreement, he replies that he would like her not to come to his neighborhood at all. The mediators demur that this is not fair: she has friends there she wants to visit. He responds that then there is nothing that he wants, refusing to pursue the conversation any further. When the mediators urge him to make another demand, claiming that this is not a one-way street but an agreement for both of them, he replies:

But she always has a one-way street, and the complaint is against me.

The mediators attempt to draw him out by asking him about his job, his friends, and his social life. They never return to the charge of statutory rape. Thus, they steer away from legal discourse and encourage Billy to think in terms of relationships. He resists, persisting with legal discourse. He sees the situation as a legal charge against him and threatens another legal charge in retaliation.

In her private discussion with the mediators, Bridget moves into moral and therapeutic discourse rather than legal. She says she thinks Billy 
needs counseling. He has refused, saying that he is not crazy. In her description of Billy's mother, she continues to talk in these terms:

Billy complains that his mother is never home. She leaves for weeks at a time and leaves him to take care of the children, and there are a lot of children he is responsible for. His older brothers beat him up. He breaks out all of the windows in his bedroom, which are now covered with boards. When I go to my girlfriend's house near his house, he sees me and then the police always get involved. He knows I go out with my friends on Friday and Saturday nights, and he always waits for me. I want him to stay away from me. He seems to be in shock, ever since I filed these charges against him. I don't think he thought I would really do it.

The mediators work out an agreement in both moral and legal discourse. Bridget agrees to drop charges of harassment against Billy providing he stops trying to see her or talk to her. Both agree to treat one another as total strangers should they accidentally see one another. The third clause reads, "Billy realizes that Mrs. Jones will immediately reactivate her charge of harassment and pursue it in court if there is the slightest breakdown in the agreement." The mediators inform Bridget and Billy, as they sign the official-looking document with a court logo at the top, that a copy will be given to the clerk and one will stay with the program, but that there will be no record of criminal charges.

Six months later it is Billy who comes into the mediation office to say that Bridget is bothering him. The mediation program writes to Bridget, who has moved back to Billy's neighborhood, and she comes into the office to say that he is still harassing her, calling her five times a night in the bar where she now works, and that she has filed a complaint against him in court. The charge is harassment and assault and battery with a knife and rocks. The written complaint application form reads as follows:

This kid refuses to leave me alone on a constant basis. He constantly harasses me and my children with his threats. If I don't talk to him he gets very violent and starts to cause trouble. All I want is this kid to leave me alone. Mediation did not work. Everybody on Green Street knows everything he does to me.

In the blank for date, she wrote, "Everyday." In contrast to the mediation session, in which she spoke of Billy as a "super person" who used to be a friend, in this application form the problem is phrased entirely in legal discourse.

The clerk-magistrate holds a 40-minute hearing to determine whether or not a complaint should be issued. Billy fails to appear, although he was summoned by the court. The first 30 minutes of this hearing are conducted largely within legal discourse. The clerk emphasizes why this is 
not a legal case but provides substantial instruction about how to present it as one. He tells Bridget she needs to provide specific dates, times, and incidents, not a general pattern of harassment. He assures Bridget that if anything else happens, she should come right into court with the specifics, but as it is, he can do nothing. Harassment is not a crime. Making threats is, however, and when he asks if Billy has ever threatened her, she brightens up and says, "Yes, all the time." But she says that Billy threatens to call the Children's Protective Services about how she mistreats her children, not to hurt her. The clerk says that is not a threat. As she tells him more about her problems and Billy's violence against her, the clerk seems more sympathetic, but still says that he must have a better legal case in order to do anything. "There is not much to go on here." Bridget describes assaults with rocks and a knife, but the clerk asks her if she has medical records.

Dates are very important. Do you know when these incidents happened? If this goes upstairs [i.e., to the judge], and the district attorney asks you for specific dates and you can't provide them, you will lose the case.

The clerk advises her to call the police, but Bridget points out that the police have stopped coming. She insists:

This has been going on for three years. Something has got to be done.

She reminds him that she has already tried mediation. When the clerk refuses to issue the complaint, she keeps repeating:

Does that mean nothing can be done? That he can just get away with this?

As she insists on her legal right to protection, the clerk takes a new tack, moving away from legal to moral discourse:

But this is also your fault, in a way. You have let this go on and on. You should have done something sooner. Now it doesn't look so convincing. And the incident you mention [which precipitated her complaint application and the mediation session] was too long ago, it is now seven months ago. The judge will say, why didn't you do something sooner? If he touches you again, come right down.

Bridget sighs and looks disgusted. Her friend, who came with her to the hearing, says,

Bridget, they have to do this legally, you know. 
The clerk concludes, in a final decisive shift to moral discourse:

I advise you to stay away from that bar. Get some beer and go home and drink it. It is better for your kids, anyway. If there is any more trouble, just come in and I will issue a complaint. You let too much time go by.

After Bridget leaves the hearing, the clerk confides to me that she is the type who goes to bars and drinks and that although he has not seen her before, he knows the friend who came with her, who is "no prize either," and he knows the bars they drink in. He also knows the neighborhood they come from, which is a bad one, and knows that the police will not do anything there. He has seen Billy in and out of juvenile court many times and is sure that he will go to jail sooner or later. His older brother is already in trouble with the law. Thus, although he responded to Bridget in legal discourse, he considered the situation in moral terms as well. $\mathrm{He}$ adds, in justifying his decision to me:

This is a serious case, it is assault and battery with a dangerous weapon, but without any dates or evidence, they will throw it out upstairs.

Although legally serious, the evidence is weak. Six months later, he told me that he never heard from Bridget again.

In the mediation session, Bridget initially phrased her problem in legal discourse, but during the session shifted to moral and therapeutic discourse under the guidance of the mediators. At the end, she said she was interested in obtaining help for Billy rather than legal sanctions. When she went back to court, however, she insisted on legal discourse, demanding protection rather than help. The clerk refused to accept her legal framing of the problem, just as the mediators had. He turned down her application for a complaint, then shifted to moral discourse and ended by offering advice. In the process, however, he provided considerable instruction in legal discourse, telling her how to present the problem if she wants the court to do something about it "next time."

\section{Neighbors and Strangers}

A third case contrasts with the previous two since it involves neighbors who are strangers. Here, the problem is initially framed more unambiguously in legal discourse. A man is complaining about the noise made by three college students who live in the apartment above him. After trying unsuccessfully to settle the case in these terms, the mediators move to moral discourse. They argue that the issue is not a matter of rights to make noise or to have quiet, but that it is really a matter of being fair to someone who is a little odd and needs special consideration and help. 
These young men were particularly resistant to the mediators' efforts to shift away from legal discourse. By calling on therapeutic discourse, however, the mediators succeed in making the transition, persuading the plaintiff not to pursue his grievance in court. The defendants agree to a very minor concession and pass up going to court themselves. Without this discourse shift, the case would have ended up in court.

The court case was initiated by a man who filed a complaint about noise against the three young men living in the apartment above him in a building located on a busy main street. The three men, all students at a local college, had moved out of the dorm into this apartment. The plaintiff, Fred, is an older man who works as a machinist in a factory. He lives in the apartment with his wife and, from time to time, a daughter from a previous marriage. He wants quiet; the students claim that they are fairly quiet, particularly in comparison to the dorm. Neither side had ever spoken to the other before; the young men said they did not even recognize the name on the court summons they received until they read the same name on the mailbox. Fred charged them with disturbing the peace. The court clerk referred the case to mediation, describing it as a "student problem."

At the mediation session, all the parties began by describing the problem as one of noise and disturbance, framing it in legal terms. Fred says that he wants to put an end to the noise and disturbance above his apartment, particularly on Sunday and Monday nights. The young men retort that they study at the library those nights. Fred comes back, "If you don't want to settle, we can take this downtown [to the court]." He points out that he complains all the time about the noise to the landlord, but that it does no good. One of the young men observes that the building is old, the walls are paper thin, and they are paying $\$ 500 /$ month rent and have the right to make some noise. Another continues,

We pay a lot of money for this apartment. We don't want to think about you whenever we walk anywhere. And we don't have loud parties, we are restrained, not like in the dorms. There it was loud.

Fred replies,

You have to live differently in an apartment.

Here the discussion shifts slightly to normative standards of quiet in different places. The young men quickly change the discussion to a complaint about Fred's failure to talk to them directly before going to court with the complaint. They assert that no one else has complained and deny again that they have parties or that they ever have more than ten people in the apartment. Fred counters that their living room is over his bedroom 
and that it sounds like a basketball is being bounced over his head. One young man responds,

We can't be conscious of every footstep.

Fred falls back on his own reputation, pointing out that no one has complained about him, and he has lived in the apartment for $2 \frac{1}{2}$ years. One young man, tall, heavy, and assertive, says he cannot change his habits of walking. All three students claim that the problem is Fred's, not theirs: they have been doing nothing out of the ordinary.

Here, the discourse is largely in terms of competing rights and evidence concerning infractions of these rights by the plaintiff and the defendants. In order to move the discussion away from this stalemate, the mediators emphasize to both sides that this is a difference in style of life, in ideas about quiet, and that they need to understand each other. Privately, the mediators decide that Fred is "very straight-laced," "kind of an oddball," and that the defendants are just boys, some of them big, who cannot really be quiet.

In the private discussion with Fred, the mediators ask for his demands and point out that what one person thinks is quiet may differ from what another person thinks is quiet. The mediator goes on:

They are big people. They can't really help the noise. They may think they are being quiet.

In the private discussion with the boys, the mediators again point out that they have different ideas of quiet and ask what they have to say, commenting that it does not sound as if they have been particularly rowdy. The mediators offer several concrete suggestions for masking the sound such as putting rubber coasters on the TV or changing the room they use as the living room. The students continue to deny that they slam doors or make noise. They ask what will happen if they refuse to sign. The mediators say that the case will go to court, and the boys quickly ask how the mediators evaluate the strength of their case. The mediators refuse, saying that they do not judge. They suggest an agreement that says that the boys will continue to be considerate, and will be careful on Sunday and Monday nights. The students resist signing anything that makes changes in their way of life. One continues:

I don't feel I should sign to do anything that I am already doing. I might be loud sometimes. I don't want my signature on that. I don't care about going to court. I don't mind. There is so much traffic noise there anyway. I am going to settle this by moving out. And what will he give? 
The mediators continue to reframe the problem in moral discourse, suggesting:

Maybe there is another way. Maybe you could sign that you are a little more aware that there is a problem and that you will continue to be considerate. You could say you are more aware of the problem.

One of the young men objects:

If we sign that, we are admitting we have done wrong. Now we are aware of his problem, but we don't need to sign it. I will sign only that I have been considerate and now am aware of the problem so I will continue to be considerate.

Another continues:

I won't change my lifestyle. I won't be quiet at 9 P.M. Movies may go on until 1 A.M.

The mediator shifts to therapeutic discourse:

But he wants to feel that you are taking his feelings into consideration. You study psychology [in college], you know he wants to feel he has some response from you.

This effort is to no avail. The men reply that they want to go to court:

We need somebody with authority to hear this. If he brings us to court, he is harassing us. I will file harassment charges against him. Let's go!

The mediator makes one more attempt:

You are all getting madder and harder in your positions. He has agreed to this. You didn't know about the problem, now you do.

Two of the young men now have to leave for work and the third stays to negotiate for them. The mediator presses moral discourse further:

If he comes to you and says it is too loud, you will know. You would then know his definition of unreasonableness. You could put things down quietly. You are dealing with a person who seems meticulous. But it takes all kinds to make a world. You have a little different kind here. If it were me, I am deaf in one ear, I wouldn't notice. But you could try to be a little more quiet. Is there anything you could sign that wouldn't mean changing your lifestyle, but give him some control? 
The other mediator returns to therapeutic discourse:

You study psychology. It is an attitude. It may be that he will only be happy if you take your shoes off at the door and whisper. You can't do anything then. But maybe if he feels he can have some say, he will feel better. To go to court may not get you any further.

After some further persuasion, the young man goes along with the shift in discourse:

So it is a consideration thing, not what my friend was saying, that this is a matter of laws, and in that regard, we don't have to be quiet. But this is a moral thing, I can see that. He is a different sort, and nothing against him for that.

This young man finally goes along with an agreement which says that he and his roommates are now aware of a problem of noise which bothers the plaintiff, and that they will continue to be considerate of him and of the other tenants in the building. Further, the man living below agrees to contact them directly if there are any further problems and to let them know the nature of the disturbance. In persuading Fred to accept the agreement, the mediators again turn to moral and therapeutic rather than legal discourse:

They feel that they 'have been careful. But now they are aware of the problem and they weren't before. They thought the problem was their shouting up for the key. Now you can call them and tell them when you are bothered. This is really a difference in lifestyles. Part of it is a misunderstanding. They didn't realize this. You never went directly to them. Now you are a human being to them. The problem is communication.

In sum, the mediators successfully shifted the discourse from a legal one, including references to rights and the authority of the court, to a moral one of consideration. The shift was aided by a few strategic references to therapeutic discourse, to understanding how the other person feels, and to the implication that Fred has some psychological weakness. When they are unable to persuade the parties to abandon their legal framework, the mediators use therapeutic discourse along with appeals to the defendants' sense of themselves as educated people ("You are college students. . . ."). This tactic finally succeeds in moving them into moral discourse, as the final statement by one of the young men indicates. The move to moral discourse is aided by the departure of the two more adamant defendants, however.

A comparison of the initial complaint with the agreement reveals the shift in discourse, a shift which moves the plaintiff away from pursuing 
his grievance in court. Each side was eager to portray itself as reasonable, but each was also anxious to defend its rights. In this case, with no previous relationship to build on, the shift away from legal discourse to moral and therapeutic ones was more difficult; the mediators accomplished the shift by references to a shared moral discourse of consideration and tolerance and by psychologically diminishing the plaintiff, subtly, in order to evoke sympathy from the young men.

This discursive shift is typical of most cases I observed. Some do not begin with as clear a legal framing as this one, although all plaintiffs have interpreted their problem in terms of some legal claim in order to justify bringing it to court in the first place. Neighborhood problems are more likely to be presented in the language of property rights and entitlements, while marital problems are more often framed in terms of rights not to be hit or to be treated fairly. Cases involving intimate relationships between women and men are often described in terms of a need for help, although this need is itself asserted as a right, rather than as a need. ${ }^{25}$ In each case, the mediators endeavor to shift the conversation to a focus on the relationship, standards of fair treatment in that relationship, and feelings rather than rights or entitlements.

Indeed, the mandate of mediation is to take problems out of the adversarial process and to discuss them in terms of relationships. But, as Silbey and $I$ argue elsewhere, the lower courts handle these problems in similar ways. ${ }^{26}$ There, too, conversation concerns how people should treat each other, the need to get along, and the importance of getting help for psychological problems. The discourses of morality and therapy are folded into the court process as well as into mediation.

Discourse shifts occur as mediators and court officials try to figure out what to do with these problems. Most mediators, court clerks, and judges are interested in providing some satisfaction, some justice for the people who bring these problems to court. They recognize the difficulty the court faces in providing what these people are seeking. They see the problems and the pain and they want to help. As they redefine these problems as unworthy of court attention and shift them into the discourses of morality or help instead of law, they provide help in ways which are consonant with the capacity of the legal system as they understand it and with their own sociocultural background. They face a dilemma created by the law's offer of more help and greater protection of rights than the courts can or will deliver to ordinary citizens.

25. On the assertion of needs rather than rights, see S. Silbey \& A. Sarat, supra note 13.

26. See Silbey \& Merry, supra note 7 . 


\section{Conclusion: The Power of Naming}

What takes place in these interactions in mediation and court is the naming of events, actions, and situations. Naming takes place within one of these three discourses, as the conversation circles around naming a teenager an "acting-out adolescent," "an irresponsible kid," or a "criminal," or naming the attentions of a young boy to an older woman "harassment," "love," or an indication that he needs help. Framing and interpreting produce different renderings and different solutions. Naming is a way in which power is exerted between third parties and disputants and among the disputants themselves. There is power both in the ability to establish names and in the consequences which flow from that labeling. The struggle to name, to determine a reigning discourse, involves all the participants in the discussions, although they have unequal resources and authority.

The power of naming is a particular kind of power in modern society, different from coercion or violence, and very subtle. In mediation and lower courts, it is a power of revealing lives and offering meaning and coherence to these lives. In mediation sessions, naming takes place in a conciliatory, participatory, and informal setting. Differences in class, education, and institutional authority all contribute to the ability of some to determine the discourses within which problems are named, differences "read" by the parties through modes of speaking, dress, sense of command, and unequal revelation of the self. This process is a form of cultural domination, for the very categories by which events are understood, and the discourses within which these categories are embedded, come to seem natural, when they are not.

The people who go to court in these communities do so not out of an eagerness to use the court, but out of a sense of entitlement: a sense that the courts are a resource which they, as citizens, have a right to use. They bring to court problems framed by their consciousness of law. They present their problems to the courts in terms of fundamental rights to protection from violence, defense of property, assertion of the authority of parents over children, or the rights of women to security from violence by men. Some go because using the law seems more civilized than using violence. Their consciousness of legal entitlement conforms to fundamental categories of the law itself: to protections for property and persons, to control over children, to management of the marriage relationship, and increasingly, to more therapeutic kinds of help available through the court.

As these plaintiffs arrive in court, however, they discover that their legal consciousness differs in subtle ways from that of the clerks, prosecutors, and mediators they meet there. The problems plaintiffs think are legally serious are interpreted by court officials as legally trivial, although 
important in terms of the morality of interpersonal relationships. Their demands to be heard as plaintiffs with a legal case are typically rejected, while they receive consideration of their problems in a social sense. Court officials, endeavoring to provide what they consider justice, convert the disputes from legal to moral or therapeutic discourse. They send them to mediation or handle them themselves, providing advice and refusing to go forward with criminal charges. Juvenile court proceedings present another example of a legalistic setting in which law is rarely raised and problems are converted to moral discourse. Thus, within the overall framework of legal institutions, plaintiffs are encouraged to reinterpret their problems as inappropriate to its legal remedies, and to reframe them as fundamentally moral concerns. By implication, the problems are not suited for the court. The legal system redefines these problems into a more powerless discourse, yet continues to provide ongoing supervision for the settlements.

These problems are invited into the court and at the same time denied legal handling. Incorporating them into the legal arena is important because they are potentially disruptive to the larger social order. But here they are only framed and contained, not offered the full panoply of litigation which brings with it an invitation to assert rights and demand change. Because these problems are handled in a blend of discourses rather than in legal terms alone, the legal claims can be deflected, transformed, extinguished while tensions ease. Problems become rephrased as cases which are then rejected as inappropriate; plaintiffs' efforts to master legal discourse and demand satisfaction are undone as their problems are named in moral and therapeutic terms, terms which deny them access to legal remedies. ${ }^{27}$

Perhaps the parties would do no better with legal solutions (however "better" is defined). But the ramifications of the shift in discourses reach beyond the problems at hand. The plaintiffs are people who feel that the law is helpful for a range of problems in their daily lives, from irascible neighbors to defective products. Insofar as they decide that the law has nothing to offer them, they begin to back away from use of the law for other kinds of problems as well.

Thus, as these working-class court users seek to assert their sense of entitlement to legal relief for these problems, they find that it is denied by the courts. The court does not reject their requests out of hand, but subjects them to periods of monitoring, to probation, to mandated social ser-

27. Neal Milner describes a similar diminishing of rights, as he terms the process, in a very different context: that of mental health rights. During the 1980 s, he argues, the assault on rights discourse produced both by the erosion of rights advocates on the bench and by a general critique of rights within the legal academy and in other organizations, has reduced the inclination of mental health groups to pursue a rights-oriented strategy for people with mental illness. See Milner, The Right to Refuse Treatment: Four Case Studies in Legal Mobilization, 21 L. \& Soc'y Rev. 447 (1987); Milner, The Dilemmas of Legal Mobilization: Ideologies and Strategies of Mental Patient Liberation Groups, 8 Law \& Pol'y Rev. 105 (1986). 
vices. The problems are denied in legal terms, but receive continuing supervision and management as moral or therapeutic problems. The plaintiffs do not find their rights protected but they do receive lectures, advice about how to organize their lives, encouragement to come back for mediation, and promises that something will be done to the defendant if the problem recurs: the complaint will be issued, the problem will go back to court, perhaps the defendant will be fined or imprisoned. The court uses its legal authority to frame the problems in other discourses, to offer non-legal solutions, and to deny the forms of protection and help promised by the legal system itself. The means for this cultural domination is the process of naming, of establishing particular interpretations, and not others, of the way events are understood and solutions specified. 